\title{
MODEL PEMBELAJARAN KOOPERATIF TIPE MAKE A MATCH BERBANTUAN MEDIA PETA PIKIRAN, KETERAMPILAN SOSIAL DAN KOMPETENSI PENGETAHUAN ILMU PENGETAHUAN SOSIAL (IPS)
}

\author{
N.A. Dewi ${ }^{1}$, I.G.A. Wesnawa ${ }^{2}$, I.W. Kertih ${ }^{3}$ \\ ${ }^{123}$ Program Studi Pendidikan IPS, Universitas Pendidikan Ganesha, Singaraja \\ e-mail: auliadewi987@gmail.com ${ }^{1}$, astra.wesnawa@undiksha.ac.id ${ }^{2}$, iwayankertih@gmail.com ${ }^{3}$
}

\begin{abstract}
Abstrak
Penelitian ini bertujuan untuk menganalisis perbedaan keterampilan sosial dan kompetensi pengetahuan IPS antara siswa yang mengikuti pembelajaran dengan model pembelajaran kooperatif tipe Make $A$ Match berbantuan media peta pikiran dengan siswa yang mengikuti pembelajaran dengan model konvensional. Penelitian ini merupakan penelitian kuantitatif dengan disain penelitian eksperimen semu melalui rancangan Posttest-Only Control Design. Populasi penelitian adalah siswa kelas VIII SMP Negeri 2 Singaraja pada tahun ajaran 2019/2020 yang berjumlah 341 orang, tersebar di sepuluh kelas. Sebelum penentuan sampel secara random sampling, dilakukan uji kesetaraan kelas dan hanya pasangan kelas yang setara dilibatkan dalam pengambilan random sampling. Berdasarkan cara tersebut, terpilih kelas VIII 4 sebagai kelas eksperimen dan kelas VIII 2 sebagai kelas kontrol dengan jumlah masing-masing sampel 34 orang. Data dikumpulkan dengan kuesioner dan tes yang selanjutnya dianalisis dengan manova untuk menguji uji hipotesis. Hasil penelitian menunjukkan bahwa: (1) terdapat perbedaan keterampilan sosial antara siswa yang mengikuti model pembelajaran kooperatif tipe Make $A$ Match berbantuan media peta pikiran dengan siswa yang mengikuti model pembelajaran konvensional dengan $\mathrm{F}$ hitung $=78,743(\mathrm{p}<0,05)$, (2) terdapat perbedaan kompetensi pengetahuan IPS antara siswa yang mengikuti model pembelajaran kooperatif tipe Make $A$ Match berbantuan media peta pikiran dengan siswa yang mengikuti model pembelajaran konvensional dengan Fhitung $=125,434(p<0,05)$, dan (3) terdapat perbedaan keterampilan sosial dan kompetensi pengetahuan IPS secara simultan antara siswa yang mengikuti model pembelajaran kooperatif tipe Make $A$ Match berbantuan media peta pikiran dengan siswa yang mengikuti model pembelajaran konvensional dengan F Wilks' Lambda $=1644,722(p<0,05)$.
\end{abstract}

Kata kunci: Keterampilan Sosial ; Kompetensi Pengetahuan IPS; Model Pembelajaran Kooperatif Tipe Make A Match; Peta Pikiran

\begin{abstract}
This study was aims to prove that there are or not the differences of social skills and IPS knowledge competence between students who followed the learning with cooperative learning model type Make A Match assisted mind map media and students who followed the learning with conventional models. The population in study were students of eighth grade of SMP Negeri 2 Singaraja in academic year 2019/2020 amounted to 341 student spread in ten classes. Prior to random sampling, a class equality test was carried out and only equivalent class pairs were involved in the random sampling. Based on this method, class VIII 4 was selected as the experimental class and class VIII 2 as the control class with a total sample of 34 people. Data were collected with questionnaires and tests. The data were analyzed by one-way ANOVA and manova. The results showed that: (1) there was differences of social skills between students who followed the learning with cooperative learning model type Make A Match assisted mind map media and students who followed the learning with conventional models with Fcount $=78.743(p<0.05)$, (2) there was differences of IPS knowledge competence between students who followed the learning with cooperative learning model type Make A Match assisted mind map media and students who followed the learning with conventional models with Fcount $=125.434(p<0.05)$, and (3) there were difference of social skills and IPS knowledge competence simultaneously between students who followed the learning with cooperative learning model type Make A Match assisted mind map media and students who followed the learning with conventional models with FWilks'Lambda $=1644.722(p<0.05)$.
\end{abstract}

Keywords: Social Skills; IPS Knowledge Competence; Cooperative Learning Model Type Make A Match; Mind Map 


\section{PENDAHULUAN}

Pendidikan adalah usaha sadar dan terencana untuk mewujudkan suasana belajar dan proses pembelajaran yang kondusif agar peserta didik secara aktif dapat mengembangkan potensi dirinya untuk memiliki kekuatan spiritual keagamaan, pengendalian diri, kepribadian, kecerdasan, akhlak mulia, serta keterampilan yang diperlukan dirinya, masyarakat, bangsa, dan negara (Sagala, 2009). Proses pendidikan seperti ini dapat mengacu pada lima pilar pendidikan yang ditetapkan oleh UNESCO, yaitu: learning to know, learning to do, learning to be, learning live together, dan learning to live sustanabilities, sehingga tujuan-tujuan mulia tadi dapat terwujud dengan baik (Dantes dkk., 2020). Jika mengacu pada pilar-pilar tersebut, maka proses pembelajaran seharusnya tidak hanya terfokus pada penguasaan materi. Pilar pendidikan belajar untuk berpengetahuan dan belajar untuk berbuat juga harus diupayakan untuk menguasai keterampilan-keterampilan pendukung lainnya, mengarahkan proses pembelajaran seyogianya mencakup pada pola berpikir dan juga bertindak.

Terdapat beberapa upaya yang dilakukan oleh pemerintah selama ini untuk upaya mencapai mutu pendidikan yang lebih baik, salah satunya adalah pembaharuan kurikulum dan penyempurnaan Kurikulum 2013. Seiring perkembangan masyarakat yang ditandai oleh perkembangan teknologi informasi dan komunikasi, tuntutan adanya reformasi pendidikan khususnya pembaruan kurikulum yang sesuai dengan perkembangan jaman menjadi hal yang sangat relevan (Suparno dkk., 2002). Upaya reformasi pendidikan telah dilakukan oleh pemerintah. Berdasar pada Permendikbud Nomor 23 Tahun 2016 tentang Stadar Penilaian Pendidikan, penilaian hasil belajar pada aspek pengetahuan, keterampilan, dan sikap yang dilakukan secara terencana dan sistematis untuk memantau proses, kemajuan belajar, dan perbaikan hasil belajar melalui penugasan dan evaluasi hasil belajar. Kegiatan pembelajaran berdasarkan Permendikbud Nomor 22 Tahun 2016 pada proses pembelajaran Kurikulum 2013 menggunakan pendekatan saintifik yang disebut 5M (mengamati, menanya, mengumpulkan informasi, mengasosiasi, dan mengomunikasikan). Penyempurnaan KTSP menjadi Kurikulum 2013 adalah upaya yang dilakukan pemerintah untuk meningkatkan mutu pendidikan agar dapat terciptanya sumber daya manusia yang berkualitas.

Upaya-upaya yang telah ditempuh pemerintah tersebut ternyata belum memberikan kualitas pembelajaran yang optimal di SMP Negeri 2 Singaraja. Pada dasarnya untuk tercapainya tujuan pendidikan yang dimaksud tidaklah dapat dilepaskan dari kegiatan pembelajaran guru sebagai peran utama dalam pendidikan. Pembelajaran merupakan kegiatan yang dilakukan untuk menginisiasi, memfasilitasi, dan meningkatkan intensitas dan kualitas belajar pada diri peserta didik. Pengamatan yang pertama, didapatkan temuan mengenai proses pembelajaran yang berlangsung di sekolah sampai saat ini pada umumnya masih bersifat konvensional, karena pembelajaran terpusat pada guru sehingga guru memegang peran yang sangat dominan. Siswa dalam pembelajaran konvensional ditempatkan sebagai objek belajar yang berperan sebagai penerima informasi secara pasif.

Hasil pengamatan lanjutan yang dilakukan pada proses pembelajaran IPS di SMP Negeri 2 Singaraja diperoleh informasi yang cenderung sama dengan kondisi yang dikemukakan pada paragraph sebelumnya, bahwa: (1) antusias belajar siswa untuk mengikuti proses pembelajaran masih tergolong rendah karena ketika guru menjelaskan materi masih ada siswa yang mengobrol dan lain-lain, (2) pada saat proses pembelajaran IPS siswa masih kurang aktif, (3) guru jarang menggunakan inovasi model pembelajaran yang menarik minat siswa untuk mengikuti proses pembelajaran, (4) guru jarang memanfaatkan inovasi media pembelajaran ataupun jarang membuat media untuk membantu dalam proses pembelajaran.

Secara umum dapat diamati dalam proses pembelajaran dan penyampaian materi IPS, guru cenderung menggunakan pembelajaran yang lebih menekankan pada proses bertutur atau ceramah. Pada dasarnya siswa sangat ingin diberikan kesempatan untuk melakukan kegiatan belajarnya sesuai dengan kebutuhan, kemampuan, dan minatnya. Persoalan mendasar di atas terjadi karena dalam praktik pembelajaran IPS siswa tidak dilibatkan aktif secara langsung, hal ini menyebabkan siswa hanya duduk diam mendengarkan penjelasan guru. Peserta didik dalam suatu proses pembelajaran tidak hanya mendengarkan penjelasan guru, melainkan juga harus berperan aktif dalam menumbuhkembangkan pengetahuan, 
sikap, dan keterampilan sehingga tujuan pembelajaran dapat tercapai. Guru sebagai salah satu komponen penting dalam proses pembelajaran harusnya menggunakan berbagai macam strategi dan media pembelajaran di samping didukung oleh penguasaan pengetahuan yang dimiliki. Proses pembelajaran dikatakan tercapai apabila ada perubahanperubahan dan peningkatan dalam diri peserta didik, baik menyangkut pengetahuan, sikap dan keterampilan untuk mencapai tujuan tersebut.

Hasil wawancara dengan guru kelas VIII SMP Negeri 2 Singaraja menyebutkan bahwa guru masih berpedoman pada buku teks. Artinya, guru menjelaskan materi sesuai dengan apa yang tercantum di buku teks. Hampir tidak ada persiapan apa-apa, hanya menyediakan satu contoh dalam pelajaran IPS, kemudian menyuruh siswa untuk mencatat. Setelah itu, ditunjuk satu atau dua siswa sebagai sampel untuk menjawab pertanyaan guru. Sedangkan untuk mencatat, guru hanya memberi perintah untuk menulis apa yang guru tuliskan di papan tulis atau mencatat dari buku teks yang dimiliki oleh guru tersebut.

Berdasarkan hasil wawancara tersebut, dapat disimpulkan bahwa pembelajaran tersebut masih berpusat kepada guru. Artinya, guru sepenuhnya memegang kendali dan mengatur jalannya proses pemikiran siswa dari awal hingga akhir, dan siswa hanya berperan pasif serta menerima saja apa yang guru mereka perintahkan. Selain itu, metode yang digunakan juga masih menggunakan metode ceramah dan guru sangat bergantung pada buku teks.

Terkait dengan keterampilan sosial siswa, dari hasil pengamatan juga menunjukkan keterampilan sosial siswa rendah. Hal ini terlihat dari siswa tidak perduli dengan orang yang datang ke sekolah, mereka asyik sendiri tanpa memperdulikan orang yang datang, saat proses pembelajaran siswa masih suka menganggu teman saat guru menjelaskan materi. Hasil observasi juga menunjukkan pada proses pembelajaran berlangsung saat guru meminta siswa mengerjakan tugas bersama kelompok siswa belum mampu bekerjasama dan masih ada siswa yang bercanda, sehingga terlihat bahwa keterampilan sosial siswa belum maksimal.

Beberapa hasil penelitian juga menemukan kondisi pembelajaran IPS di SMP Negeri 2 Singaraja masih rendah. Salah satu penelitian yang dilakukan oleh Yuliastini (2017), yang menemukan bahwa nilai rata-rata ulangan akhir semester ganjil pada mata pelajaran IPS siswa kelas VII SMP Negeri 2 Singaraja masih tergolong rendah. Rata-rata hasil ulangan akhir semester ganjil siswa kelas VIII untuk mata pelajaran IPS masih di bawah Kriteria Ketuntasan Maksimal (KKM). Parbawa dan Sujana (2018) menunjukkan bahwa kompetensi pengetahuan IPS siswa masih jauh dari yang diharapkan karena kurangnya interaksi antara siswa dan guru, siswa dengan siswa lain, maupun siswa dengan sumber belajarnya sehingga kurang berpartisipasi secara aktif dan masih banyak siswa mendapat nilai rendah diantara nilai mata pelajaran lain.

Berdasarkan pemaparan permasalahan tersebut, terdapat permasalahan pada kompetensi pengetahuan IPS dan keterampilan social siswa. Dalam kaitannya dengan permasalahan tersebut, maka diperlukan suatu solusi yang dapat mengatasi permasalahan rendahnya kompetensi pengetahuan IPS dan keterampilan sosial siswa. Salah satu solusinya adalah menerapkan model pembelajaran inovatif yang mampu meningkatkan minat dan keaktifan siswa dalam mengikuti proses pembelajaran, menekankan pada adanya interaksi dan kerjasama serta meningkatkan pemahaman siswa terhadap konsep-konsep pembelajaran IPS. Dalam kaitannya dengan hal tersebut, model pembelajaran kooperatif dapat mengatasi permasalahan tersebut. Menurut Rusman (2017) pembelajaran kooperatif merupakan suatu pendekatan yang lebih mengutamakan bekerjasama pada kelompok.

Huda (2015) menyatakan bahwa pembelajaran kooperatif ini menghendaki peserta didik untuk saling membantu dalam belajar dan saling kerjasama dalam kelompok sesuai dengan metode pembelajaran yang dipilih guru. Menurut Slavin (2010) model pembelajaran kooperatif merujuk pada berbagai macam metode pengajaran untuk siswa bekerja secara berkelompok untuk saling membantu satu sama lainnya dalam mempelajari materi pelajaran. Siswa diharapkan dapat saling membantu, saling mendiskusikan dan beragumentasi, untuk mengasah pengetahuan yang mereka kuasai saat itu dan menutup kesenjangan dalam pemahaman masing-masing. Menurut Arends (2013), tujuan pembelajaran kooperatif ada 
ketika siswa menganggap bahwa mereka dapat mencapai tujuan mereka jika, siswa lain yang bekerja sama dengan mereka dapat juga mencapai tujuan. Fatimah (2017) mengungkapkan bahwa mengajar dengan menggunakan pembelajaran kooperatif dapat meningkatkan keterampilan sosial.

Berdasarkan beberapa pendapat tersebut, model pembelajaran kooperatif memberikan kesempatan kepada siswa bekerja sama saling membantu, memotivasi, mengkonstruksi konsep, menyelesaikan persoalan secara bersama-sama untuk mencapai tujuan bersama dalam pembelajaran. Model ini memiliki keunggulan untuk dapat mengembangkan kemampuan mengungkapkan argumentasi, sehingga dapat meningkatkan partisipasi siswa sehingga tanya jawab dapat berlangsung dengan baik yang mendorong pembangunan pengetahuan dan keterampilan social yang terintegrasi. Konsep inilah yang menjadi dasar bahwa model pembelajaran kooperatif mampu mengatasi permasalahan kompetensi pengetahuan IPS dan keterampilan sosial siswa.

Dalam kaitannya dengan permasalahan penelitian, yaitu permasalahan pembelajaran siswa terkait dengan kurangnya antusias belajar siswa, kurang keaktifnya siswa, rendahnya hasil belajar IPS, dan rendahnya keterampilan sosial yang ditunjukkan dengan kurangnya interaksi dan kerja sama siswa, maka dari itu dibutuhkanlah penerapan model pembelajaran yang relevan dengan karkateristik permasalahan sekolah di atas. Model pembelajaran kooperatif tipe Make $A$ Match dinilai yang relevan sebagai solusi atas permesalahan pembelajaran tersebut. Hal ini disebabkan karena kelebihan dari model pembelajaran Make A Match adalah (1) mewujudkan kondisi pembelajaran yang menyenangkan, (2) materi belajar disajikan lebih menarik perhatian peserta didik, (3) dapat memperbaiki hasil belajar peserta didik guna mencapai taraf ketuntasan belajar, (4) kerjasama antarsesama peserta didik terwujud dengan dinamis (Kurniasih dan Berlin, 2015). Dari beberapa kelebihan yang dimiliki oleh pembelajaran kooperatif tipe make a match, pembelajaran IPS diharapkan menjadi lebih bermakna untuk siswa. Siswa ikut terlibat aktif saat kegiatan pembelajaran, hingga siswa merasa gembira, asyik, dan berminat dalam menerima materi pelajaran. Diskusi yang terdapat pada model pembelajaran kooperatif tipe Make A Match dapat membuat siswa mudah memahami konsep-konsep IPS dan memunculkan banyak ide. Selain itu, adanya peraturan, menunggu giliran bermain, menemukan kecocokan pasangan kartu juga akan membantu siswa mendapatkan keterampilan sosial (Riyanti, 2018). Hal ini menunjukkan bahwa model pembelajaran kooperatif tipe Make A Match dapat mengatasi permasalahan rendahnya kompetensi pengetahuan IPS dan keterampilan sosial siswa.

Model Make A Match adalah model pembelajaran dimana peserta didik belajar dalam kondisi yang mengasyikkan dengan cara mencari pasangan sembari mempelajari suatu konsep dan topik tertentu (Huda, 2015). Model pembelajaran Make A Match memiliki hubungan yang erat dengan karakteristik siswa yang gemar bermain (Shoimin, 2014). Pelaksanaan model Make $A$ Match harus didukung dengan keaktifan siswa untuk bergerak mencari pasangan dengan kartu sesuai jawaban atau pertanyaan dalam kartu tersebut. Dalam pembelajaran model Make A Match, suasana belajar di kelas diciptakan sebagai suasana permainan karena adanya kompetisi diantara siswa untuk memecahkan masalah terkait dengan materi pelajaran dan adanya reward atau penghargaan. Dengan adanya unsur permainan dalam suatu proses pembelajaran maka menjadikan pembelajaran lebih menarik dan menyenangkan. Oleh karena itu, guru dapat menerapkan model pembelajaran kooperatif tipe Make A Match ini pada pembelajaran IPS sehingga siswa akan lebih tertarik dan lebih aktif dalam mengikuti kegiatan pembelajaran.

Alasan utama memilih model pembelajaran kooperatif tipe Make A Match, karena pada penerapan model ini proses pemebelajaran akan lebih menarik minat siswa dan menyenangkan sehingga akan berpengaruh terhadap peningkatan hasil belajar. Dengan menggunakan model ini siswa akan terlibat langsung dalam menjawab soal yang diberikan kepadanya melalui kartu, menghindari kejenuhan siswa dalam mengikuti kegiatan belajar mengajar dan meningkatkan minat belajar siswa. Untuk mengoptimalkan proses pembelajaran dan untuk lebih menarik perhatian siswa dalam belajar, maka penerapan model pembelajaraan kooperatif tipe Make A Match ini dintegrasikan dengan sebuah media pembelajaran peta pikiran. Kontribusi nilai peta pikiran dalam pembelajaran sangat besar 
dibanding dengan media konvensional (Faridah, 2014). Penguasaan materi siswa dengan menggunakan peta pikiran mencapai peningkatan sehingga peta pikiran sangat efektik digunakan dalam pembelajaran (Sari, 2016). Peta pikiran sangat efektif digunakan sebab selain hasilnya lebih baik dibanding dengan penggunaan media yang lain, juga dapat menghemat waktu (Bukhari, 2016). Penerapan peta pikiran model menunjukkan hasil yang positif, karena dalam peta pikiran siswa selama pembelajaran diberikan kesempatan berkomunikasi dengan teman lainnya dalam memecahkan masalah yang diberikan, siswa juga dapat mengembangkan kreativitas melalui kerjasama dalam mencatat kata kunci kemudian merancang peta pikirannya dengan begitu siswa lebih mudah mengingat dan memahami pembelajaran (Syam dan Ramlah, 2015).

Menurut Buzan (2009), peta pikiran memudahkan untuk menempatkan informasi ke dalam otak dan mengambil informasi keluar. Senada dengan itu, Yuliani dkk. (2017) menyatakan bahwa peta pikiran adalah cara untuk mempermudah siswa agar memahami konsep-konsep yang telah dipelajari oleh siswa. Windura (2010) menyatakan peta pikiran merupakan media untuk menempatkan informasi ke dalam otak dan mengambilnya kembali keluar otak. Peta pikiran mengembangkan cara berpikir divergen, berpikir kreatif, efektif, dan secara harfiah akan memetakan konsep-konsep. Peta pikiran dapat membantu siswa berpikir secara kreatif sekaligus kritis, mengingat dengan baik materi pelajaran, memahami isi bacaan, dan penugasan lain yang diberikan. Peta pikiran mengajarkan untuk mencatat tidak hanya menggunakan tulisan, tetapi juga menggunakan gambar. Dengan menggunakan media ini dapat membuat siswa lebih bisa memahami materi yang dijelaskan guru karena siswa akan mencatat poin-poin penting materi tersebut ke dalam bentuk catatan kreatif seperti peta rute yang mempunyai banyak cabang dan juga bisa dibuat lebih menarik dengan menambahkan gambar serta bentuk-bentuk yang menarik minat siswa.

\section{METODE}

Penelitian ini dikatagorikan kuasi eksperimen. Desain ini dipilih karena eksperimen dilakukan di beberapa kelas tertentu dengan siswa yang telah ada atau sebagaimana adanya. Rancangan eksperimen yang dipilih adalah rancangan Post-Test Only Control Design. Populasi dalam penelitian ini adalah seluruh siswa kelas VIII SMP Negeri 2 Singaraja pada tahun ajaran 2019/2020, dengan jumlah 341 orang yang tersebar dalam sepuluh kelas pararel. Berdasarkan hasil kesetaraan semua kelas VIII SMP Negeri 2 Singaraja memiliki kemampuan yang setara maka bisa dilakukan dengan random sampling. Dua kelas dijadikan sampel penelitian, satu kelas sebagai kelas eksperimen dan satu kelas sebagai kelas kontrol. Data dikumpulkan dengan kuesioner dan tes serta dianalisis dengan anova dan manova satu jalur dengan uji F.

\section{HASIL DAN PEMBAHASAN Hasil}

Hipotesis pertama yang diajukan dalam penelitian ini adalah terdapat perbedaan keterampilan sosial antara siswa yang mengikuti pembelajaran dengan model pembelajaran kooperatif tipe Make $A$ Match berbantuan media peta pikiran dengan siswa yang mengikuti pembelajaran dengan model konvensional di kelas VIII SMP Negeri 2 Singaraja. Pengujian hipotesis pertama dengan analisis varian satu jalur. Hipotesis yang diuji secara statistik adalah $\mathrm{H}_{0}$. Kriteria penolakan $\mathrm{H}_{0}$ jika harga $\mathrm{F}$ memiliki angka signifikansi lebih kecil dari 0,05. Rekapitulasi hasil analisis varian satu jalur disajikan pada Tabel 1.

Tabel 1. Rekapitulasi Hasil Analisis Varian Satu Jalur untuk Keterampilan Sosial ANOVA

\begin{tabular}{lccccl}
\hline & Sum of Squares & $d f$ & Mean Square & $F$ & Sig. \\
\hline Between Groups & 4896,015 & 1 & 4896,015 & 78,743 & 0,000 \\
Within Groups & 4103,676 & 66 & 62,177 & & \\
Total & 8999,691 & 67 & & & \\
\hline
\end{tabular}


Berdasarkan rekapitulasi hasil analisis varian satu jalur yang disajikan pada Tabel 1 dapat ditunjukkan bahwa nilai $F=78,743(p<0,05)$, sehingga $\mathrm{H}_{0}$ yang menyatakan tidak terdapat perbedaan keterampilan sosial antara siswa yang mengikuti pembelajaran dengan model pembelajaran kooperatif tipe Make $A$ Match berbantuan media peta pikiran dengan siswa yang mengikuti pembelajaran dengan model konvensional di kelas VIII SMP Negeri 2 Singaraja ditolak. Jadi, terdapat perbedaan keterampilan sosial antara siswa yang mengikuti pembelajaran dengan model pembelajaran kooperatif tipe Make A Match berbantuan media peta pikiran dengan siswa yang mengikuti pembelajaran dengan model konvensional di kelas VIII SMP Negeri 2 Singaraja.

Hipotesis kedua yang diajukan dalam penelitian ini adalah terdapat perbedaan kompetensi pengetahuan IPS antara siswa yang mengikuti pembelajaran dengan model pembelajaran kooperatif tipe Make $A$ Match berbantuan media peta pikiran dengan siswa yang mengikuti pembelajaran dengan model konvensional di kelas VIII SMP Negeri 2 Singaraja. Pengujian hipotesis kedua dengan analisis varian satu jalur. Hipotesis yang diuji secara statistik adalah $\mathrm{H}_{0}$. Kriteria penolakan $\mathrm{H}_{0}$ jika harga $\mathrm{F}$ memiliki angka signifikansi lebih kecil dari 0,05. Rekapitulasi hasil analisis varian satu jalur disajikan pada Tabel 2.

Tabel 2. Rekapitulasi Hasil Analisis Varian Satu Jalur untuk Kompetensi Pengetahuan IPS ANOVA

\begin{tabular}{llllll}
\hline & Sum of Squares & Df & Mean Square & $F$ & Sig. \\
\hline Between Groups & 4224,941 & 1 & 4224,941 & 125,434 & 0,000 \\
Within Groups & 2223,059 & 66 & 33,683 & & \\
Total & 6448,000 & 67 & & & \\
\hline
\end{tabular}

Berdasarkan rekapitulasi hasil analisis varian satu jalur yang disajikan pada Tabel 2 dapat ditunjukkan bahwa nilai $F=125,434(p<0,05)$, sehingga $\mathrm{H}_{0}$ yang menyatakan tidak terdapat perbedaan kompetensi pengetahuan IPS antara siswa yang mengikuti pembelajaran dengan model pembelajaran kooperatif tipe Make A Match berbantuan media peta pikiran dengan siswa yang mengikuti pembelajaran dengan model konvensional di kelas VIII SMP Negeri 2 Singaraja ditolak. Jadi, terdapat perbedaan kompetensi pengetahuan IPS antara siswa yang mengikuti pembelajaran dengan model pembelajaran kooperatif tipe Make $A$ Match berbantuan media peta pikiran dengan siswa yang mengikuti pembelajaran dengan model konvensional di kelas VIII SMP Negeri 2 Singaraja.

Hipotesis ketiga yang diajukan dalam penelitian ini adalah terdapat perbedaan keterampilan sosial dan kompetensi pengetahuan IPS secara simultan (bersama-sama) antara siswa yang mengikuti pembelajaran dengan model pembelajaran kooperatif tipe Make A Match berbantuan media peta pikiran dengan siswa yang mengikuti pembelajaran dengan model konvensional di kelas VIII SMP Negeri 2 Singaraja. Pengujian hipotesis ketiga dengan manova satu jalur. Hipotesis yang diuji secara statistik adalah $\mathrm{H}_{0}$. Kriteria penolakan $\mathrm{H}_{0}$ jika taraf signifikansi untuk statistik Wilks' Lambda lebih kecil dari 0,05. Rekapitulasi hasil hasil uji manova satu jalur tersaji pada Tabel 3.

Tabel 3. Rekapitulasi Hasil Manova Satu Jalur Multivariate Tests

\begin{tabular}{llllcl}
\hline Effect & Value & $F$ & Hypothesis df & Error df & Sig. \\
\hline Pillai's Trace & 0,981 & 1644,722 & 2,000 & 65,000 & 0,000 \\
Wilks' Lambda & 0,019 & 1644,722 & 2,000 & 65,000 & 0,000 \\
Hotelling's Trace & 50,607 & 1644,722 & 2,000 & 65,000 & 0,000 \\
Roy's Largest Root & 50,607 & 1644,722 & 2,000 & 65,000 & 0,000 \\
\hline
\end{tabular}

Berdasarkan ringkasan analisis manova satu jalur yang disajikan pada Tabel 3, dapat diinterpretasikan bahwa taraf signifikansi untuk nilai F-Wilks' Lambda $=1644,722(p<0,05)$, sehingga $\mathrm{H}_{0}$ yang menyatakan tidak terdapat perbedaan keterampilan sosial dan kompetensi pengetahuan IPS secara simultan (bersama-sama) antara siswa yang mengikuti pembelajaran dengan model pembelajaran kooperatif tipe Make A Match berbantuan media 
peta pikiran dengan siswa yang mengikuti pembelajaran dengan model konvensional di kelas VIII SMP Negeri 2 Singaraja ditolak. Jadi, terdapat perbedaan keterampilan sosial dan kompetensi pengetahuan IPS secara simultan (bersama-sama) antara siswa yang mengikuti pembelajaran dengan model pembelajaran kooperatif tipe Make A Match berbantuan media peta pikiran dengan siswa yang mengikuti pembelajaran dengan model konvensional di kelas VIII SMP Negeri 2 Singaraja.

\section{Pembahasan}

Untuk permasalahan pertama, hasil analisis dengan analisis varians satu jalur diperoleh bahwa nilai $F=78,743(p<0,05)$. Oleh karena itu, hipotesis nol $\left(H_{0}\right)$ yang menyatakan bahwa tidak terdapat perbedaan keterampilan sosial antara siswa yang mengikuti pembelajaran dengan model pembelajaran kooperatif tipe Make $A$ Match berbantuan media peta pikiran dengan siswa yang mengikuti pembelajaran dengan model konvensional di kelas VIII SMP Negeri 2 Singaraja ditolak. Jadi, terdapat perbedaan keterampilan sosial antara siswa yang mengikuti pembelajaran dengan model pembelajaran kooperatif tipe Make A Match berbantuan media peta pikiran dengan siswa yang mengikuti pembelajaran dengan model konvensional.

Hasil analisis deskriptif menunjukkan bahwa perbedaan keterampilan sosial siswa yang mengikuti pembelajaran dengan model pembelajaran kooperatif tipe Make $A$ Match berbantuan media peta pikiran dengan skor rata-rata 117,71, sedangkan keterampilan sosial siswa yang mengikuti pembelajaran dengan model konvensional dengan skor rata-rata 100,74. Ternyata skor rata-rata keterampilan sosial siswa yang mengikuti pembelajaran dengan model pembelajaran kooperatif tipe Make A Match berbantuan media peta pikiran lebih tinggi daripada siswa yang mengikuti pembelajaran dengan model konvensional. Dengan demikian, dapat disimpulkan keterampilan sosial siswa yang mengikuti pembelajaran dengan model pembelajaran kooperatif tipe Make A Match berbantuan media peta pikiran lebih unggul daripada siswa yang mengikuti pembelajaran dengan model konvensional.

Keterampilan sosial mungkin terkait dengan kompetensi akademik anak-anak dan kesuksesan di masa depan. ini mengangkat pertanyaan tentang peran keterampilan sosial diajar, sebagai faktor internal, dalam memprediksi prestasi kesenjangan dalam kerangka ekologi selain memperhitungkan pengaruh eksternal (Liu, 2011). Keterampilan sosial muncul dari pengalaman langsung yang dialami oleh siswa dan keterampilan sosial siswa tersebut muncul karena adanya interaksi sosial yang dialami oleh individu tersebut (Azwar, 2003). Oleh karena itu, model pembelajaran Make $A$ Match berbantuan media peta pikiran sangat sesuai diterapkan untuk mengembangkan keterampilan sosial siswa. Hal ini disebabkan karena kelebihan dari model pembelajaran Make A Match adalah (1) mewujudkan kondisi pembelajaran yang mengasyikkan dan kerjasama antarsesama peserta didik terwujud dengan dinamis (Kurniasih dan Berlin, 2015). Model Make $A$ Match adalah model pembelajaran dimana peserta didik belajar dalam kondisi yang mengasyikkan dengan cara mencari pasangan sembari mempelajari suatu konsep dan topik tertentu (Huda, 2015). Model pembelajaran Make $A$ Match memiliki hubungan yang erat dengan karakteristik siswa yang gemar bermain (Shoimin, 2014). Pelaksanaan model Make A Match harus didukung dengan keaktifan siswa untuk bergerak mencari pasangan dengan kartu sesuai jawaban atau pertanyaan dalam kartu tersebut. Adanya peraturan, menunggu giliran bermain, menemukan kecocokan pasangan kartu juga akan membantu siswa mendapatkan keterampilan sosial (Riyanti, 2018).

Dari kelebihan tersebut, model pembelajaran Make A Match berbantuan peta pikiran ini mampu meningkatkan keaktifan siswa, kerjasama siswa karena suasana pembelajaran dibuat menyenangkan dengan bekerja dalam kelompok untuk memecahkan masalah sehingga akan ada interaksi antara siswa tersebut. Adanya interaksi antara siswa ini akan mampu memupuk keterampilan sosial siswa tersebut.

Berbeda dengan dalam pembelajaran IPS dengan menggunakan pembelajaran konvensional, lebih menekankan pada fungsi guru sebagai pemberi informasi. Siswa hanya pasif mendengarkan penjelasan guru tanpa dilibatkan secara aktif dalam pembelajaran. 
Guru menjelaskan dari konsep, definisi, pengertian sampai pada contoh-contoh. Siswa baru terlibat jika ada soal yang diberikan oleh guru dan lebih bersifat teks book. Kreatifitas siswa kurang berkembang, sehingga akan berakibat pada kurang maksimalnya keterampilan sosial siswa karena sangat jarang memberikan kepada siswa untuk berpendapat.

Secara empiris, hasil penelitian ini didukung oleh hasil penelitian terdahulu yang dilakukan oleh Apriyani (2016) menunjukkan bahwa model pembelajaran Cooperative Learning tipe Make A Match berpengaruh positif terhadap keterampilan sosial siswa. Hasil penelitian yang sama juga ditunjukkan oleh Fitriani (2017), yang menunjukkan bahwa adanya peningkatan keterampilan sosial dan hasil belajar siswa terjadi karena penerapan pendekatan Make A Match berbantuan kartu bergambar. Hasil penelitian yang sama juga ditunjukkan oleh Nurfitasari (2018), yang menunjukkan bahwa adanya peningkatan keterampilan sosial setelah menggunakan model pembelajaran kooperatif tipe Make a Match.

Untuk permasalahan kedua, hasil analisis dengan analisis varians satu jalur diperoleh bahwa nilai $F=125,434(p<0,05)$. Oleh karena itu, hipotesis nol $\left(\mathrm{H}_{0}\right)$ yang menyatakan bahwa tidak terdapat perbedaan kompetensi pengetahuan IPS antara siswa yang mengikuti pembelajaran dengan model pembelajaran kooperatif tipe Make A Match berbantuan media peta pikiran dengan siswa yang mengikuti pembelajaran dengan model konvensional di kelas VIII SMP Negeri 2 Singaraja ditolak. Jadi, terdapat perbedaan kompetensi pengetahuan IPS antara siswa yang mengikuti pembelajaran dengan model pembelajaran kooperatif tipe Make $A$ Match berbantuan media peta pikiran dengan siswa yang mengikuti pembelajaran dengan model konvensional.

Hasil analisis deskriptif menunjukkan bahwa perbedaan kompetensi pengetahuan IPS siswa yang mengikuti pembelajaran dengan model pembelajaran kooperatif tipe Make $A$ Match berbantuan media peta pikiran dengan skor rata-rata 73,88 , sedangkan kompetensi pengetahuan IPS siswa yang mengikuti pembelajaran dengan model konvensional dengan skor rata-rata 58,12. Ternyata skor rata-rata kompetensi pengetahuan IPS siswa yang mengikuti pembelajaran dengan model pembelajaran kooperatif tipe Make $A$ Match berbantuan media peta pikiran lebih tinggi daripada siswa yang mengikuti pembelajaran dengan model konvensional. Dengan demikian, dapat disimpulkan kompetensi pengetahuan IPS siswa yang mengikuti pembelajaran dengan model pembelajaran kooperatif tipe Make $A$ Match berbantuan media peta pikiran lebih unggul daripada siswa yang mengikuti pembelajaran dengan model konvensional.

Model pembelajaraan kooperatif tipe Make A Match dapat meningkatkan meningkatkan pemahaman siswa terhadap materi yang dipelajari, efektif untuk melatih keberanian siswa, dan melatih kedisiplinan siswa untuk menghargai waktu belajar (Huda, 2014). kelebihan dari model pembelajaran Make A Match adalah materi belajar disajikan lebih menarik perhatian peserta didik dan dapat memperbaiki hasil belajar peserta didik guna mencapai taraf ketuntasan belajar (Kurniasih dan Berlin, 2015:56). Dari kelebihan yang dimiliki oleh pembelajaran kooperatif tipe make a match, pembelajaran IPS diharapkan menjadi lebih bermakna untuk siswa. Siswa ikut terlibat aktif saat kegiatan pembelajaran, hingga siswa merasa gembira, asyik, dan berminat dalam menerima materi pelajaran. Diskusi yang terdapat pada model pembelajaran kooperatif tipe Make A Match dapat membuat siswa mudah memahami konsep-konsep IPS dan memunculkan banyak ide.

Peta pikiran memudahkan untuk menempatkan informasi ke dalam otak dan mengambil informasi keluar (Buzan, 2009). Peta pikiran adalah cara untuk mempermudah siswa agar memahami konsep-konsep yang telah dipelajari oleh siswa (Yuliani dkk. (2017). Peta pikiran dapat membantu siswa berpikir secara kreatif sekaligus kritis, mengingat dengan baik materi pelajaran, memahami isi bacaan, dan penugasan lain yang diberikan. Pada model pembelajaran kooperatif tipe Make $A$ Match siswa diajak untuk mencari pasangan kartu soal dan kartu jawaban mengenai suatu topik serta siswa juga dituntut untuk memecahkan suatu masalah serta siswa dapat bertanggung jawab dalam menyelesaikan tugasnya dalam suasana yang menyenangkan dengan didukung oleh media peta pikiran yang akan memudahkan siswa untuk memahami materi yang dijelaskan. Dengan demikian, 
model pembelajaran kooperatif tipe Make $A$ Match diyakini mampu meningkatkan kompetensi pengetahuan siswa khususnya pada muatan materi IPS.

Berbeda dengan pembelajaran IPS dengan menggunakan pembelajaran konvensional, siswa kurang mendapatkan kesempatan belajar dengan pengalaman sehari-hari. Dengan demikian, belajar IPS seolah-seolah belajar konsep-konsep atau prinsip-prinsip IPS yang tidak ada kaitannya dengan kehidupan anak. Oleh karena itu, pengetahuan anak tentang IPS sebatas pengetahuan yang ada pada buku serta apa yang diberikan oleh guru. Hal ini akan melemahkan semangat siswa untuk belajar, sehingga kompetensi pengetahuan siswa tidak tercapai secara optimal.

Secara empiris, hasil penelitian ini didukung oleh hasil penelitian terdahulu yang dilakukan oleh Suryani dkk. (2017) menunjukkan model pembelajaran Make A Match Berbantuan Media Permainan TTS mempengaruhi kompetensi pengetahuan IPS dibandingkan dengan kelompok siswa yang dibelajarkan melalui pembelajaran konvensional. Penelitian lainnya dilakukan oleh Gading dan Kharisma (2017), yang mengungkapkan bahwa model pembelajaran Make $A$ Match berbantuan media audio visual mempengaruhi hasil belajar IPS antara kelompok siswa yang diberi perlakuan menggunakan model pembelajaran Make A Match berbantuan media audio visual dengan kelompok siswa yang tidak diberi perlakuan menggunakan model pembelajaran Make A Match berbantuan media audio visual.

Untuk permasalahan ketiga, hasil analisis dengan manova satu jalur tampak bahwa nilai F-Wilks' Lambda $=1644,722(p<0,05)$. Oleh karena itu, hipotesis nol $\left(H_{0}\right)$ yang menyatakan bahwa tidak terdapat perbedaan keterampilan sosial dan kompetensi pengetahuan IPS secara simultan (bersama-sama) antara siswa yang mengikuti pembelajaran dengan model pembelajaran kooperatif tipe Make A Match berbantuan media peta pikiran dengan siswa yang mengikuti pembelajaran dengan model konvensional di kelas VIII SMP Negeri 2 Singaraja ditolak. Jadi, terdapat perbedaan keterampilan sosial dan kompetensi pengetahuan IPS secara simultan (bersama-sama) antara siswa yang mengikuti pembelajaran dengan model pembelajaran kooperatif tipe Make A Match berbantuan media peta pikiran dengan siswa yang mengikuti pembelajaran dengan model konvensional di kelas VIII SMP Negeri 2 Singaraja.

Model pembelajaran kooperatif tipe Make $A$ Match berbantuan media peta pikiran dapat mengembangkan keterampilan sosial dan kompetensi pengetahuan IPS siswa. Hal ini disebabkan karena kelebihan dari model pembelajaran Make $A$ Match adalah mewujudkan kondisi pembelajaran yang mengasyikkan, materi belajar disajikan lebih menarik perhatian peserta didik, dapat memperbaiki hasil belajar peserta didik guna mencapai taraf ketuntasan belajar, kerjasama antarsesama peserta didik terwujud dengan dinamis (Kurniasih dan Berlin, 2015). Dari beberapa kelebihan yang dimiliki oleh pembelajaran kooperatif tipe make a match, pembelajaran IPS diharapkan menjadi lebih bermakna untuk siswa. Siswa ikut terlibat aktif saat kegiatan pembelajaran, hingga siswa merasa gembira, asyik, dan berminat dalam menerima materi pelajaran. Diskusi yang terdapat pada model pembelajaran kooperatif tipe Make A Match dapat membuat siswa mudah memahami konsep-konsep IPS dan memunculkan banyak ide. Selain itu, adanya peraturan, menunggu giliran bermain, menemukan kecocokan pasangan kartu juga akan membantu siswa mendapatkan keterampilan sosial (Riyanti, 2018). Saat anak mengembangkan kehidupan sosialnya dan mulai berinteraksi dengan anak lain yang seumuran. Mereka dihadapkan pada harapan tambahan sosial dan mulai belajar keterampilan seperti memulai dan mempertahankan interaksi berbagi mainan dan alat permainan serta bermain dengan baik bersama temannya (Koyama, 2011). Hal ini menunjukkan bahwa model pembelajaran kooperatif tipe Make $A$ Match dapat mengatasi permasalahan rendahnya kompetensi pengetahuan IPS dan keterampilan sosial siswa. Hal ini menunjukkan bahwa model pembelajaran kooperatif tipe Make A Match dapat mengatasi permasalahan rendahnya kompetensi pengetahuan IPS dan keterampilan sosial siswa.

Model Make A Match adalah model pembelajaran dimana peserta didik belajar dalam kondisi yang mengasyikkan dengan cara mencari pasangan sembari mempelajari suatu konsep dan topik tertentu (Huda, 2015). Model pembelajaran Make A Match memiliki 
hubungan yang erat dengan karakteristik siswa yang gemar bermain (Shoimin, 2014). Pelaksanaan model Make $A$ Match harus didukung dengan keaktifan siswa untuk bergerak mencari pasangan dengan kartu sesuai jawaban atau pertanyaan dalam kartu tersebut. Dalam pembelajaran model Make $A$ Match, suasana belajar di kelas diciptakan sebagai suasana permainan karena adanya kompetisi diantara siswa untuk memecahkan masalah terkait dengan materi pelajaran dan adanya reward atau penghargaan. Dengan adanya unsur permainan dalam suatu proses pembelajaran maka menjadikan pembelajaran lebih menarik dan menyenangkan. Oleh karena itu, guru dapat menerapkan model pembelajaran kooperatif tipe Make A Match ini pada pembelajaran IPS sehingga siswa akan lebih tertarik dan lebih aktif dalam mengikuti kegiatan pembelajaran.

Untuk mengoptimalkan proses pembelajaran serta untuk lebih menarik perhatian siswa dalam belajar, maka penerapan model pembelajaraan kooperatif tipe Make $A$ Match ini dintegrasikan dengan sebuah media pembelajaran. Media pembelajaran adalah segala sesuatu yang dapat menyalurkan pesan atau bahan pembelajaran yang dapat merangsang perhatian, minat, perasaan dan pikiran siswa. Media pembelajaran yang digunakan dalam pembelajaran ini adalah media peta pikiran. Menurut Buzan (2009), peta pikiran memudahkan untuk menempatkan informasi ke dalam otak dan mengambil informasi keluar. Senada dengan itu, Yuliani dkk. (2017) menyatakan bahwa peta pikiran adalah cara untuk mempermudah siswa agar memahami konsep-konsep yang telah dipelajari oleh siswa. Windura (2010) menyatakan peta pikiran merupakan media untuk menempatkan informasi ke dalam otak dan mengambilnya kembali keluar otak. Peta pikiran mengembangkan cara berpikir divergen, berpikir kreatif, efektif, dan secara harfiah akan memetakan konsepkonsep. Peta pikiran dapat membantu siswa berpikir secara kreatif sekaligus kritis, mengingat dengan baik materi pelajaran, memahami isi bacaan, dan penugasan lain yang diberikan. Peta pikiran mengajarkan untuk mencatat tidak hanya menggunakan tulisan, tetapi juga menggunakan gambar. Dengan menggunakan media ini dapat membuat siswa lebih bisa memahami materi yang dijelaskan guru karena siswa akan mencatat poin-poin penting materi tersebut ke dalam bentuk catatan kreatif seperti peta rute yang mempunyai banyak cabang dan juga bisa dibuat lebih menarik dengan menambahkan gambar serta bentuk-bentuk yang menarik minat siswa.

Berbeda dengan pembelajaran IPS dengan menggunakan pembelajaran konvensional, lebih menekankan pada fungsi guru sebagai pemberi informasi. Siswa hanya pasif mendengarkan penjelasan guru tanpa dilibatkan secara aktif dalam pembelajaran. Guru menjelaskan dari konsep, definisi, pengertian sampai pada contoh-contoh. Siswa baru terlibat jika ada soal yang diberikan oleh guru dan lebih bersifat teks book. Kreatifitas siswa kurang berkembang, sehingga akan berakibat pada kurang maksimalnya hasil belajar siswa. Sebagai bentuk perbandingan, pembelajaran konvensional lebih didominasi oleh kegiatan guru untuk memberikan instruksi atau ceramah selama proses pembelajaran berlangsung. Hal ini jelas akan menempatkan siswa sebagai penerima informasi yang pasif dan hanya menerima informasi dari guru. Proses pembelajaran cenderung kurang didasarkan pada pengalaman siswa. Hal ini tidak memberikan kesempatan mengembangkan keterampilan sosial dan kompetensi pengetahuan IPS siswa.

Secara empiris, hasil penelitian ini didukung oleh hasil penelitian terdahulu yang dilakukan oleh Suryani dkk. (2017) menunjukkan model pembelajaran Make A Match Berbantuan Media Permainan TTS mempengaruhi kompetensi pengetahuan IPS dibandingkan dengan kelompok siswa yang dibelajarkan melalui pembelajaran konvensional. Hasil penelitian oleh Aliputri (2018) menunjukkan bahwa adanya peningkatan hasil belajar IPS tentang kegiatan ekonomi setelah menggunakan model pembelajaran kooperatif tipe Make a Match Berbantuan Kartu Bergambar.

\section{SIMPULAN DAN SARAN}

Berdasarkan analisis data dan pembahasan seperti yang telah diuraikan pada bagian sebelumnya, dapat ditemukan beberapa hal, yaitu (1) terdapat perbedaan keterampilan sosial antara siswa yang mengikuti pembelajaran dengan model pembelajaran kooperatif tipe Make $A$ Match berbantuan media peta pikiran dengan siswa yang mengikuti 
pembelajaran dengan model konvensional di kelas VIII SMP Negeri 2 Singaraja, (2) terdapat perbedaan kompetensi pengetahuan IPS antara siswa yang mengikuti pembelajaran dengan model pembelajaran kooperatif tipe Make $A$ Match berbantuan media peta pikiran dengan siswa yang mengikuti pembelajaran dengan model konvensional di kelas VIII SMP Negeri 2 Singaraja, dan (3) terdapat perbedaan keterampilan sosial dan kompetensi pengetahuan IPS secara simultan (bersama-sama) antara siswa yang mengikuti pembelajaran dengan model pembelajaran kooperatif tipe Make $A$ Match berbantuan media peta pikiran dengan siswa yang mengikuti pembelajaran dengan model konvensional di kelas VIII SMP Negeri 2 Singaraja.

Berkenaan dengan hasil penelitian yang diperoleh, beberapa saran yang dapat diajukan adalah sebagai berikut. Pertama, dengan mengacu pada hasil temuan penelitian ini disarankan kepada siswa supaya memperoleh pengalaman belajar yang lebih bermakna sehingga siswa menjadi lebih menguasai materi, kompetensi pengetahuan dapat meningkat, dan memiliki keterampilan sosial yang baik. Di samping itu, guru diharapkan dapat memvariasikan proses pembelajaran yang dilakukan di kelas dengan menerapkan model pembelajaran atau penggunaan media pembelajaran seperti model pembelajaran make a match berbantuan peta pikiran agar mampu mengembangkan kemampuan dan pemahamannya. Kepala sekolah juga diharapkan mampu untuk menyediakan fasilitas dan pemberian pelatihan tentang variasi dalam proses pembelajaran seperti penerapan model pembelajaran atau media pembelajaran guna mendukung proses pembelajaran. Kedua, penelitian lanjutan yang berkaitan dengan model pembelajaraan kooperatif tipe Make $A$ Match dalam pembelajaran IPS perlu dilakukan dengan materi-materi IPS yang lain dengan melibatkan sampel yang lebih luas. Selain itu, perlu pula dilakukan penelitian yang mengkaji media peta pikiran guna peningkatan kualitas proses untuk mencapai keterampilan sosial dan kompetensi pengetahuan IPS yang maksimal. Penggunaan variabel lain seperti minat dan motivasi, yang merupakan bagian yang tidak terpisahkan dari siswa perlu dikaji pengaruhnya terhadap pengembangan dan penerapan model pembelajaraan kooperatif tipe Make A Match serta dampaknya terhadap kualitas proses pembelajaran IPS.

\section{DAFTAR RUJUKAN}

Aliputri, Dhestha Hazilla. 2018. Penerapan Model Pembelajaran Kooperatif Tipe Make A Match Berbantuan Kartu Bergambar Untuk Meningkatkan Hasil Belajar Siswa. Jurnal Bidang Pendidikan Dasar (JBPD), 2(1), Hal: 70-77.

Apriyani, Al. Maryanto. 2016. Pengaruh Model Cooperative Learning Tipe Make A Match dalam Pembelajaran IPA Terhadap Keterampilan Sosial dan Hasil Belajar Kognitif Siswa SMP. Jurnal Pendidikan IImu Pengetahuan Alam, 5(9), Hal: 1-7.

Arends, Richard I. 2013. Belajar Untuk Mengajar, Learning to Teach. Jakarta: Salemba Humanika.

Azwar, Saifuddin. 2003. Sikap Manusia Teori dan Pengukurannya. Yogyakarta:Pustaka Pelajar.

Bukhori, A. R. D. S. (2015). Development Lerarning Model f Character Education Through EComic In Elementary School. International. Journal of Education and Research, 3(9), 1-12.

Buzan, Tony. 2009. Buku Pintar Mind Maps. Jakarta: Gramedia.

Faridah, E. 2014. Pengaruh Penerapan Strategi Peta Pikiran (Mind Mapping) Terhadap Hasil Belajar IPA terpadu Tema Es Lilin Siswa Kelas VIII SMPN 4 Jombang. Jurnal Pensa, 2(1), 1-10.

Fatimah, lis Daniati. 2017. Penerapan Model Pembelajaran Make A Match dengan Media Kartu Bergambar untuk Meningkatkan Motivasi dan Hasil Belajar Siswa. IImu Pendidikan, 2(1), Hal: 28-37. 
Fitriani. 2017. Penerapan Model Kooperatif Tipe Make A Match Berbantuan Kartu Bergambar untuk Meningkatkan Keterampilan Sosial dan Hasil Belajar IPS. Jurnal Pendidikan: Teori, Penelitian, dan Pengembangan, 2(12), Hal: 1577-1584.

Gading, Ketut dan Kadek Dian Kharisma. 2017. Pengaruh Model Pembelajaran Kooperatif Tipe Make A Match Berbantuan Media Audio Visual Terhadap Hasil Belajar IPS Sekolah Dasar. International Journal of Elementary Education, 1(2), Hal: 153-160.

Harjanti, D. T., Ningrum, E., dan Yani, A. 2014. Penerapan Teknik Peta Pikiran (Mind Map) Untuk Meningkatkan Pemahaman Konsep Geografi Pada Peserta Didik Kelas XI-2 IPS SMAN 1 Rasau Jaya Kabupaten Kubu Raya. Jurnal Gea Volume, 14(2), 92-98.

Huda, Miftahul. 2015. Cooperative Learning: Metode, Teknik, Struktur dan Model Terapan. Yogyakarta: Pustaka Pelajar.

Humaerah, R., Bahri, A., dan Ristiana, E. 2020. Pengaruh Penggunaan Peta Pikiran Terhadap Peningkatan Hasil Belajar IPA Siswa di Sekolah Dasar. Jurnal Review Pendidikan Dasar: Jurnal Kajian Pendidikan dan Hasil Penelitian, 6(1), 1-6.

Koyama, T. 2011. The Effects of Social Skills Groups For Young Children With Social Delays. International of Journal Education Reseach, 1(4).

Kurniasih, Imas dan Berlin Sani. 2015. Ragam Pengembangan Model Pembelajaran untuk Peningkatan Profesionalitas Guru. Yogyakarta: Kata Pena.

Lasmawan, I Wayan. 2015. Pengaruh Model Pembelajaran Kooperatif Teknik Make A Match Terhadap Motivasi Belajar Dan Hasil Belajar IPS. Jurnal Pendidikan Dasar Indonesia, 5, Hal: 1-12.

Liu, X. 2011. Young Children's Social Skills Development and Academic Achievement: Longitudinal Analysis of Developmental Trajectories and Enviornmental Influences. International of Education Reseach, 4(7), 423-441.

Nurfitasari, Wulan. 2018. Peningkatan Keterampilan Sosial dan Hasil Belajar Ips Menggunakan Model Pembelajaran Make A Match. Jurnal Pendidikan Guru Sekolah Dasar, 31(7), Hal: 3073-3083.

Parbawa, I Gusti Ngurah Made Anom dan I Wayan Sujana. 2018. Pengaruh Model Pembelajaran Visual Auditory Kinestetik dan Motivasi Belajar terhadap Kompetensi Pengetahuan IPS Siswa Kelas IV. Jurnal IImiah Sekolah Dasar, 2(1), Hal: 68-72.

Riyanti, Nisrohah Neni. 2018. Penerapan Model Pembelajaran Kooperatif Tipe Make A Match untuk Meningkatkan Hasil Belajar IPS. JPGSD, 6(4), Hal: 440-450.

Rusman. 2017. Belajar \& Pembelajaran Berorientasi Standar Proses Pendidikan. Jakarta: Kencana.

Sagala, Syaiful. 2009. Konsep dan Makna Pembelajaran. Bandung: Alfabeta.

Sari, S. A., dan Halimatun, S. 2016. The Development of Mind Mapping Media in Flood Material Using ADDIE Model. Journal of Education and Learning, 10(1), 1-10.

Shoimin, Aris. 2014. 68 Model Pembelajaran Inovatif dalam Kurikulum 2013. Yogyakarta: ArRuzz Media.

Slavin, R. E. 2010. Cooperative Learning Teori, Riset dan Praktik. Bandung: Nusa Media.

Suparno, Paul, R. Rohandi, G. Sukadi, dan S. Kartono. 2002. Reformasi Pendidikan: Sebuah Rekomendasi. Yogyakarta: Kanisius.

Suryani, Dewa Ayu Putri, I Wayan Sujana, dan Ida Bagus Gede Surya Abadi. 2017. Pengaruh Model Pembelajaran Make A Match Berbantuan Media permainan TTS Terhadap Kompetensi Pengetahuan IPS Siswa Kelas V SD Gugus I Dalung. Mimbar PGSD, 5(2), Hal: 1-9. 
Syam, N., dan Ramlah. 2015. Penerapan Model Pembelajaran Mind Mapping Dalam Meningkatkan Hasil Belajar Pada Mata Pelajaran IImu Pengetahuan Sosial Siswa Kelas IV SDN 54 Kota Parepare. Jurnal Publikasi Pendidikan, 5(3), 184-197.

Windura, Susanto. 2010. Mind Map Langkah Demi Langkah. Jakarta: Gramedia.

Yuliani, Ni Putu, Gede Margunayasa, dan Desak Putu Parmiti. 2017. Pengaruh Model Pembelajaran POGIL Berbantuan Peta Pikiran terhadap Hasil Belajar IPA Siswa Kelas V SD. Journal of Education Technology, 1(2), Hal: 117-123.

Yuliastini, N. L. G. S. 2017. Pengaruh Model Take And Give Berbantuan Multimedia Interaktif Terhadap Hasil Belajar IPS. e-Journal Edutech Universitas Pendidikan Ganesha, 3(1), Hal: 1-10. 